\title{
Home range of green turtles Chelonia mydas at a coastal foraging area in the Gulf of California, Mexico
}

\author{
Jeffrey A. Seminoff ${ }^{1, *}$, Antonio Resendiz ${ }^{2}$, Wallace J. Nichols ${ }^{3,4}$ \\ ${ }^{1}$ Archie Carr Center for Sea Turtle Research and Department of Zoology, University of Florida, PO Box 118525, Gainesville, \\ Florida 32611-8525, USA \\ ${ }^{2}$ Instituto Nacional de Ecología, Direccíon General de Vida Silvestre, Secretaria de Medio Ambiente y Recursos Naturales, \\ Ensenada, Baja California, Mexico \\ ${ }^{3}$ Department of Herpetology, California Academy of Sciences, Golden Gate Park, San Francisco, California 94118, USA \\ ${ }^{4}$ Wildcoast International Conservation Team, PO Box 324, Davenport, California 95017, USA
}

\begin{abstract}
The green turtle Chelonia mydas is a circumglobal species that is susceptible to overexploitation as a food resource and incidental mortality in fisheries. Efforts to recover regional green turtle populations have been hampered by a lack of information on their biology. In particular, turtle movements and home ranges in neritic foraging habitats are not well understood. Thus, wildlife managers cannot accurately determine the habitat needs of green turtle populations. To address these understudied aspects, we carried out the first ever investigation of green turtle home range in neritic foraging habitats of the eastern Pacific Ocean. Twelve turtles, ranging from 50.9 to $82.5 \mathrm{~cm}$ in straight carapace length and from 17 to $70 \mathrm{~kg}$ in mass, were tracked with radio and sonic telemetry for 34 to $96 \mathrm{~d}$ at the Bahía de los Angeles foraging area in the Gulf of California, Mexico. Home range areas determined with minimum convex polygon and fixed kernel density estimator methods ranged from 584 to 3908 ha $($ mean $=1662 \pm 324$ ha) and 409 to 3231 ha (mean $=1537 \pm 280$ ha), respectively. There was no evidence that straight carapace length, mass, sex, tracking duration or number of re-sightings influenced the size of the home range. Green turtle home ranges contained from 1 to 3 activity centers ranging from 3.8 to 642.2 ha in area (mean $=178.8 \pm 62.0$ ha). Turtles were re-sighted in all depth-class regions ( 0 to $10 \mathrm{~m}$ to $40+\mathrm{m}$ ) in the study area but were not found with equal frequency among these regions. The distribution of re-sightings among depth classes varied significantly between diurnal (05:00 to 18:59 h) and nocturnal (19:00 to 04:59 h) periods. While the greatest frequency of diurnal re-sightings occurred in the 10 to $20 \mathrm{~m}$ depth class, nocturnal encounters were most frequent in the 0 to $10 \mathrm{~m}$ depth class. This study shows that Bahía de los Angeles remains an important feeding ground; thus, underscoring the need to develop conservation strategies that address the impacts of ongoing commercial marine-algae harvests and net fisheries that threaten green turtles in this region.
\end{abstract}

KEY WORDS: Eastern Pacific Ocean $\cdot$ Sea of Cortez $\cdot$ Black turtle $\cdot$ Wildlife telemetry $\cdot$ Fixed kernel density estimator $\cdot$ Minimum convex polygon

\section{INTRODUCTION}

${ }^{*}$ Present address: Southwest Fisheries Science Center, NOAA, National Marine Fisheries Service, 8604 La Jolla Shores Drive, La Jolla, California 92037, USA.

E-mail: jeffrey.seminoff@noaa.gov
Green turtles Chelonia mydas occur in tropical and subtropical regions throughout the world's oceans. Due to overexploitation of eggs and turtles as a food resource and, to a lesser extent, incidental mortality 
relating to marine fisheries and degradation of marine and nesting habitats, populations have declined throughout the world (Groombridge \& Luxmoore 1989, Limpus 1995). Green turtles are currently listed as endangered in the World Conservation Union (IUCN) Red Data Book (Hilton-Taylor 2000) and are included in Appendix 1 of the Convention on International Trade in Endangered Species of Wild Fauna and Flora (CITES). Despite a worldwide increase in research and conservation of green turtles, their foraging biology and habitat requirements remain poorly understood (Bjorndal 1997).

In the eastern Pacific Ocean, green turtles (also known as black turtles) have experienced substantial declines due to human overexploitation (Caldwell 1963, Cliffton et al. 1982, Figueroa et al. 1993). The annual nesting population at the primary rookery in Michoacán was estimated at $\sim 25000$ females in the early 1970s (Cliffton et al. 1982) but has since dropped to fewer than 500 females (Alvarado-Díaz et al. 2001). The decline has been largely attributed to continued harvest of green turtles from neritic habitats of the eastern Pacific Ocean, particularly near Baja California (Alvarado \& Figueroa 1992, Seminoff 2000, Gardner \& Nichols 2001). Despite calls for increased protection (National Marine Fisheries Service and US Fish and Wildlife Service 1998), conservation efforts have been hindered by a poor understanding of the critical foraging grounds and the patterns of habitat use in this region.

Like most sea turtles, green turtles are migratory and use a wide range of broadly separated localities and habitats during their lifetime (for review see Hirth 1997). Upon leaving the nesting beach, it has been hypothesized that hatchlings begin an oceanic phase, perhaps floating passively in major current systems (gyres) for several years (Carr \& Meylan 1980, Carr 1987). These turtles are then thought to recruit from oceanic waters to neritic developmental habitats rich in seagrass and/or marine algae, where they forage and grow until maturity (Musick \& Limpus 1997). Upon attaining sexual maturity, green turtles commence breeding migrations between foraging grounds and nesting areas that are undertaken in multiple year intervals (Hirth 1997). Migrations are carried out by males and females, and may traverse oceanic zones, often spanning 1000s of km (Carr 1986, Mortimer \& Portier 1989). During non-breeding periods adults reside at neritic feeding grounds that may coincide with juvenile developmental habitats (Limpus et al. 1994).

A fundamental biological component of green turtles resident to neritic habitats is the use of a home range, defined as the area traversed by an animal during normal daily activities, excluding migrations or erratic movements (Bailey 1984). Defining a home range re- quires the repeated sighting of individuals over extended time intervals (White \& Garrott 1990). Because sea turtles spend $99 \%$ of their lives underwater, home range studies require remote telemetry or in-water capture programs that are both labor-intensive and expensive. Few investigations have been undertaken as a result. Home ranges of green turtles in Florida (Mendonca 1983), Texas (Renaud et al. 1995) and Australia (Whiting \& Miller 1998) have been studied using radio and sonic telemetry. Additionally, Renaud \& Carpenter (1994) used positions obtained from satellite telemetry to determine home ranges of loggerhead turtles in the Gulf of Mexico, and van Dam \& Diez (1998) evaluated home range areas for hawksbill turtles in Puerto Rico based on mark-recapture and sonic telemetry data.

A variety of techniques have been developed to evaluate home ranges but few have been applied to sea turtles. The minimum convex polygon (MCP) technique, which identifies home range as the area within the polygon formed by joining the outermost re-sighting positions of an animal (Burt 1943), has been most commonly applied (Mendonca 1983, Renaud \& Carpenter 1994, Renaud et al. 1995, Whiting \& Miller 1998). Although the MCP calculation is very intuitive, this approach is highly sensitive to outlying observations and is constrained by its inability to identify finescale spatial use patterns within the home range boundary (White \& Garrott 1990). In contrast, novel non-parametric methods have been developed to identify 1 or more areas of disproportionately heavy use (i.e. core areas) within a home range boundary (for review see Worton 1987, 1989, White \& Garrott 1990). For instance, Renaud \& Carpenter (1994) used the harmonic mean estimator (Dixon \& Chapman 1980) to reveal up to 3 core patches for loggerhead sea turtles in the Gulf of Mexico. However, although the harmonic mean estimator is able to highlight discontinuities in spatial use within home range boundaries, it is sensitive to outlying re-sightings and is thus prone to overestimating home range size (Seaman \& Powell 1996). More recently, non-parametric kernel approaches have been developed (Worton 1987, 1989) that can reveal multiple core areas and appropriately weigh outlying observations. Seaman \& Powell (1996) evaluated the fixed kernel density (FKD) estimator and suggested this approach is the most accurate home range assessment technique. In marine ecosystems, kernel methods have been used to delineate the foraging grounds of satellite tracked seabirds (GonzalezSolis et al. 2000, Wood et al. 2000, Hyrenbach et al. 2002), and although the FKD estimator has not yet been used extensively with water-borne marine organisms, it represents a promising technique for estimating sea turtle home range. 
Understanding spatial use patterns of sea turtles is fundamental to their conservation. Knowledge about home ranges can identify critical habitats and guide decisions regarding the management of endangered populations (Bailey 1984). Thus, home range study should be an important component of any green turtle recovery effort. In this paper, we describe the home ranges of green turtles at a coastal foraging area in the central Gulf of California. Green turtles were tracked with radio and sonic telemetry, and home range areas were determined with both the MCP and FKD methods. This is the first study of green turtle home range in the eastern Pacific Ocean and, to our knowledge, the first application of non-parametric kernel density estimators for study of sea turtle home ranges.

\section{MATERIALS AND METHODS}

Study area. The study was conducted from August 1997 to August 2000 at Bahía de los Angeles (28 58' N, $\left.113^{\circ} 33^{\prime} \mathrm{W}\right)$, a NNE-oriented bay along the western coast of the Baja California peninsula, Mexico (Fig. 1). Bahía de los Angeles is $\sim 60 \mathrm{~km}^{2}$ in area, and charac-

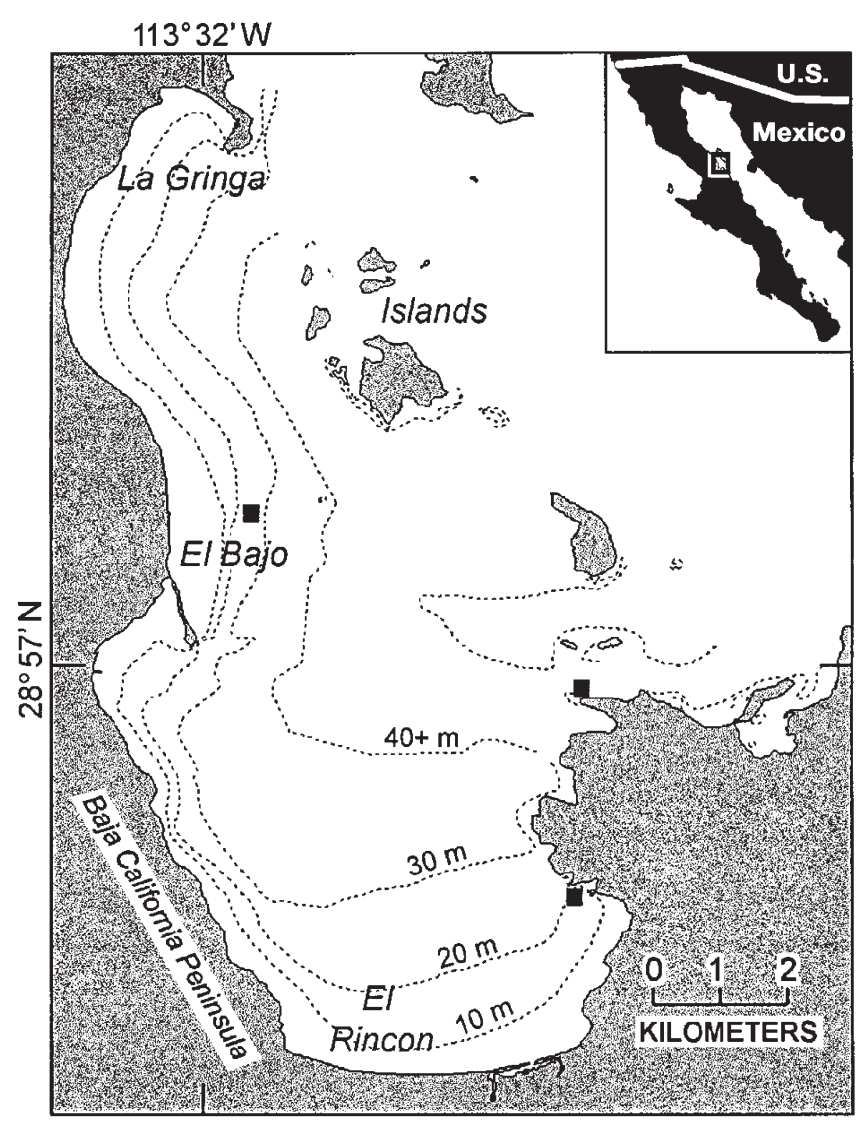

Fig. 1. Bahía de los Angeles study area, Gulf of California, Mexico. (ם) Sites of ocean temperature measurement terized by strong tidal mixing and upwelling, which supports productive marine benthic communities (Bray \& Robles 1991). This foraging ground contains 3 main marine algae localities: (1) La Gringa, a south-facing protected cove at the northern boundary of the study area with multiple stands of red and brown algae; (2) El Bajo, an extensive shallow water $(<10 \mathrm{~m})$ region along the western edge of the study site that supports the area's largest perennial red algae pasture; and (3) El Rincon, a horseshoe-shaped bay marking the southern boundary of the study area that hosts winter annual stands of red algae. A series of 17 islands line the eastern portion of Bahía de los Angeles and separate this feeding area from deep offshore waters of the central Gulf of California. Benthic habitats at these islands are characterized by boulder fields that steeply descend 40 to $50 \mathrm{~m}$ to the soft-bottomed sea floor. Marine invertebrates such as gorgonians and soft corals are abundant (Brusca 1980). Habitat characteristics of Bahía de los Angeles are further described in Seminoff (2000).

Turtle capture and measurement. We captured green turtles with entanglement nets $(100 \times 8 \mathrm{~m}$, mesh size $=$ $50 \mathrm{~cm}$ stretched) placed along the shallow perimeter of the study area. Distance of netting sites from shore ranged from 50 to $750 \mathrm{~m}$ and water depth ranged from 2 to $27 \mathrm{~m}$. Nets were set during both day and night, and monitored at $0.5 \mathrm{~h}$ intervals. Upon capture, turtles were transported 1 to $8 \mathrm{~km}$ to a holding facility where they were measured, weighed and tagged.

Straight carapace length $\left(\mathrm{SCL}_{;} \pm 0.1 \mathrm{~cm}\right)$ was measured from the nuchal notch to the posterior-most portion of the rear marginals using a forester's caliper. We measured tail length $\left(\mathrm{TL}_{i} \pm 1.0 \mathrm{~cm}\right.$ ) from the tip of the tail to the trailing edge of the carapace using a flexible tape measure. Green turtles possessing an elongated tail (TL $\geq 20 \mathrm{~cm}$ ) were classified as male (Wibbels 1999). Sex was undetermined for individuals with nonelongated tails (TL $<20 \mathrm{~cm}$ ). Turtles were weighed to the nearest $\mathrm{kg}$ using a $150 \mathrm{~kg}$ spring balance and tagged with Inconel tags (Style 681, National Band and Tag), in the first large proximal scale of each rear flipper.

Tracking. Green turtles were instrumented with a very high frequency (VHF) radio transmitter (MOD 400, Telonics) and a sonic transmitter (V16, VEMCO or DT96, Sonotronics). We attached VHF transmitters to the crown of the carapace using fiberglass cloth and resin (Balazs et al. 1996). The anterior and posterior ends of VHF transmitters were fit with fairings made with 10 min quick-set putty to reduce hydrodynamic drag. Sonic transmitters were affixed to the carapace posterior with electrician 'tie-wraps' fit through two $3 \mathrm{~mm}$ diameter holes drilled in the marginal scutes (Renaud et al. 1995). Location of transmitters did not 
interfere with flipper movements. Mass of transmitter packages ranged from 250 to $400 \mathrm{~g}$ ( 0.5 to $1.2 \%$ of turtle body mass). Radio transmission frequencies ranged from 148.00 to $148.99 \mathrm{mHz}$. Sonic transmissions were 28.0 to $55.0 \mathrm{kHz}$, a frequency range that is outside the hearing capacity of green turtles $(30 \mathrm{~Hz}$ to $1 \mathrm{kHz}$; Ridgeway et al. 1969).

Instrumented turtles were released at their initial capture site within $24 \mathrm{~h}$ and tracking began after a $24 \mathrm{~h}$ acclimation period. We attempted to re-sight each turtle at least once a day during the tracking season or until it was determined that transmitters had detached. We used a VHF receiver (TR-4, Telonics) with a 3-element Yagi antenna to determine the general location of each turtle. Maximum reception range of VHF transmissions was $\sim 12 \mathrm{~km}$ but the origin of transmission became indistinguishable within $\sim 0.25 \mathrm{~km}$ of tracked turtles. We therefore pinpointed a turtle's location using sonic telemetry. Sonic transmissions were monitored with a sonic receiver (VR60, VEMCO) with a directional hydrophone. Maximum reception range of sonic signals was $\sim 2 \mathrm{~km}$ and signal origin was distinguishable to within $\sim 5 \mathrm{~m}$ of tracked turtles. Sonic tracking was used exclusively when a turtle had lost its VHF tag but retained its sonic tag. A $12 \mathrm{ft}$ (3.6 m) inflatable boat (Achilles) with $25 \mathrm{hp}$ outboard motor was used for all tracking efforts. To minimize disturbance to the turtles, each re-sighting position was determined by maneuvering the tracking vessel to within 10 to $20 \mathrm{~m}$ of the turtle and recording the location of the tracking vessel with a global positioning system (Garmin; error range = \pm 3 to $12 \mathrm{~m}$ ). Distances from telemetered turtles were determined through direct observation of surfacing turtles or estimated from the strength of the sonic signal at 1/10 gain with a directional hydrophone.

The water depth at each re-sighting coordinate was determined with a bathymetric chart of the study area and classified as occurring within 1 of 5 depth classes that are delineated on the chart: 0-10, 10-20, 20-30, 30-40 and $40+\mathrm{m}$ (Fig. 1). Water temperatures were logged continuously in 3 regions of the bay using remote temperature sensors (Onset Computers; Fig. 1).

Analysis of home range area. We estimated home range areas with the MCP (Burt 1943) and FKD (Worton 1987,1989$)$ methods using the animal movement analyst extension (US Geological Survey, Anchorage, Alaska; www.absc.usgs.gov/glba/gistools/\#animal) for the ArcView version 3.1 geographic information system (GIS) software (Environmental Research Systems Institute; www.esri.com/software/arcview). Minimum convex polygon areas were based on the $100 \%$ outer edges. Fixed kernel home ranges were calculated with least-square cross validation as a smoothing parameter (Silverman 1986, Seaman \& Powell 1996). A $95 \%$ utilization distribution (UD) was used to estimate the overall home range used by a turtle, whereas a $50 \%$ UD was used to establish the core area of activity (Worton 1989, White \& Garrott 1990). To minimize serial correlation, home range analyses included re-sighting positions temporally separated by $\geq 4 \mathrm{~h}$ (Swihart \& Slade 1985, Hansteen et al. 1997, Schmid et al. 2002).

Statistical methods. The relationship between home range size (log MCP and log FKD) and home range predictors (year, log SCL, log mass, sex, tracking duration and number of re-sightings) was analyzed statistically using general linear modeling (GLM; see Cohen \& Cohen 1983). The MCP and FKD home range area estimates for each individual turtle were compared with a Wilcoxon rank sum test. To examine how each home range area estimate was influenced by the duration of tracking, we plotted the percent of the final MCP area estimate for each turtle as a function of the tracking interval (i.e. increment plots; Kenward 2001). An asymptote of this relationship indicates a robust home range estimate (Kenward 2001). A mean increment plot for all turtles was used to identify the overall relationship between the number of tracking days and the MCP home range area. A Pearson Chi-square test was used to determine if the frequency of re-sightings was equal among depth classes during the diel (24 h), diurnal (05:00 to $18: 59 \mathrm{~h})$ and nocturnal (19:00 to $04: 59 \mathrm{~h}$ ) periods. We compared the distributions of resightings among depth classes for the diurnal versus nocturnal periods using the Kolmogorov-Smirnov 2-sample test. Statistical analyses were conducted with the JMP software (SAS Institute 1996). Mean values and standard errors $( \pm \mathrm{SE})$ are reported throughout this paper.

\section{RESULTS}

\section{Tracking effort}

A total of 12 green turtles ranging from 50.9 to $82.5 \mathrm{~cm}$ in straight carapace length and 16.8 to $70.4 \mathrm{~kg}$ in mass were tracked (Table 1). Three individuals were identified as males (CM2, CM8 and CM11) and the genders of the remainder were not classified. These turtles were captured at 6 different localities (Fig. 2) and tracked for 34 to $96 \mathrm{~d}$ (mean $=59.7 \pm 5.4 \mathrm{~d}$ ). One turtle was tracked from August to October 1997, 5 between June and October 1998, 5 between June and September 1999, and 1 from July to August 2000 (Table 1). Sea surface temperatures during these tracking periods ranged from 23.0 to $29.1^{\circ} \mathrm{C}$.

A total of 444 re-sightings occurred during the study: 370 in daylight and 74 at night. Individual turtles were re-sighted from 16 to 61 times (mean $=37.1 \pm 4.2$ resightings; Table 1). Tracking of 5 turtles was ceased 

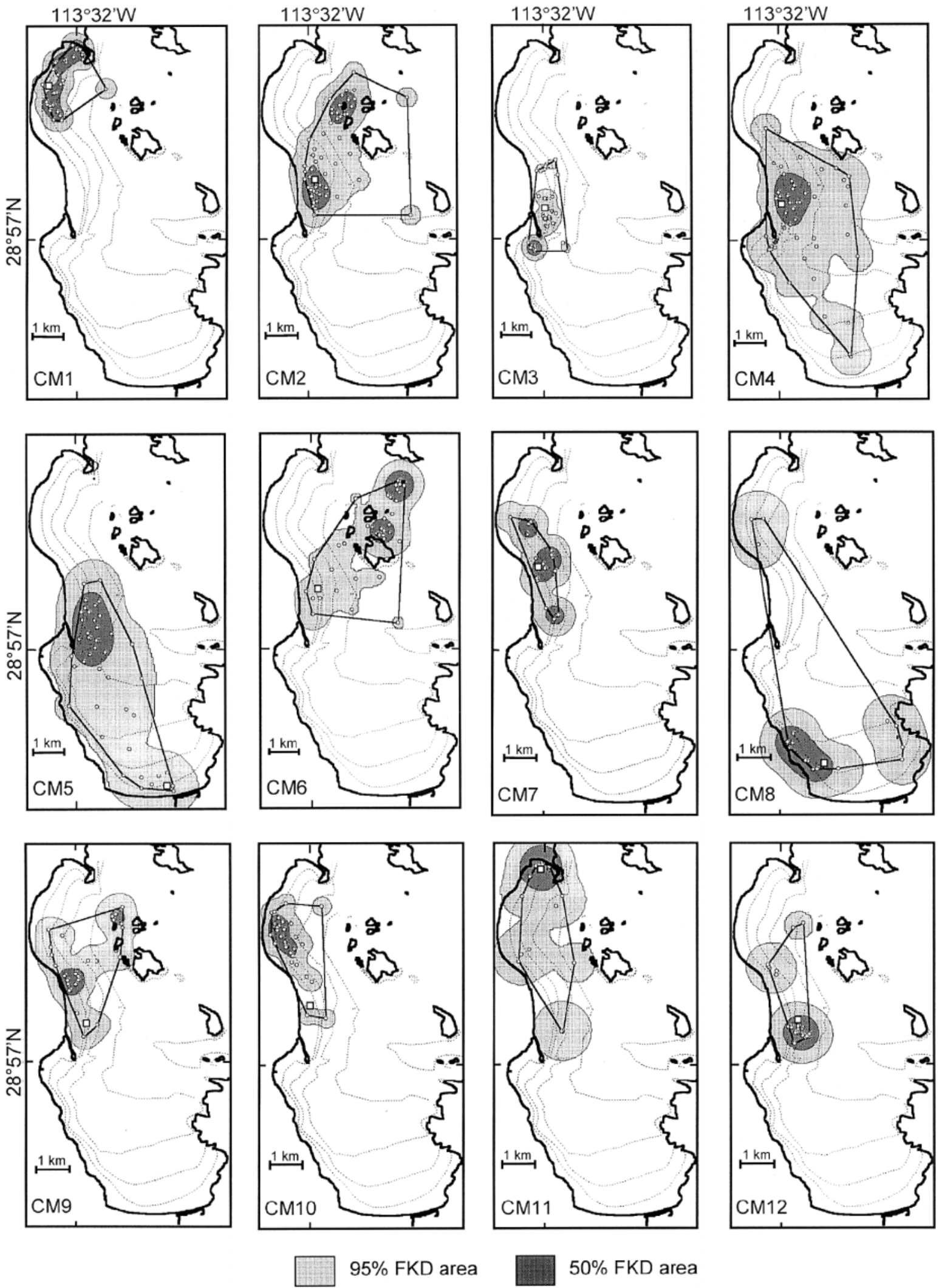

Fig. 2. Chelonia mydas. Home range maps for 12 green turtles tracked during this study. Solid lines are minimum convex polygons, shaded areas are fixed kernel density estimator areas. ( $\square$ ) Initial capture sites 
Table 1. Chelonia mydas. Summary of the physical traits, tracking intervals and home range areas for 12 green turtles tracked in Bahía de los Angeles. SCL: straight carapace length; M: male; U: undetermined; $n$ : number of re-sightings; MCP: minimum convex polygon; FKD: fixed kernel density home range estimator

\begin{tabular}{|c|c|c|c|c|c|c|c|c|}
\hline $\begin{array}{l}\text { Turtle } \\
\text { ID }\end{array}$ & $\begin{array}{l}\mathrm{SCL} \\
(\mathrm{cm})\end{array}$ & $\begin{array}{c}\text { Mass } \\
(\mathrm{kg})\end{array}$ & Sex & $\begin{array}{l}\text { Tracking interval } \\
\text { (mm/dd/yy) }\end{array}$ & $\begin{array}{l}\text { Total } \\
\text { days }\end{array}$ & $\mathrm{n}$ & $\begin{array}{c}\mathrm{MCP} \\
\text { (ha) }\end{array}$ & $\begin{array}{l}\text { FKD } \\
\text { (ha) }\end{array}$ \\
\hline CM1 & 70.4 & 58 & $\mathrm{U}$ & 08/28/97-10/06/97 & 40 & 32 & 648 & 760 \\
\hline CM2 & 77.5 & 70 & M & $06 / 25 / 98-08 / 29 / 98$ & 65 & 55 & 2395 & 2183 \\
\hline CM3 & 65.2 & 41 & $\mathrm{U}$ & 06/24/98-10/01/98 & 96 & 46 & 697 & 409 \\
\hline $\mathrm{CM} 4$ & 71.4 & 50 & $\mathrm{U}$ & 07/02/98-08/19/98 & 77 & 45 & 2833 & 2994 \\
\hline CM5 & 69.0 & 45 & $\mathrm{U}$ & $-08 / 29 / 98$ & 48 & 43 & 2775 & 3231 \\
\hline CM6 & 65.3 & 41 & $\mathrm{U}$ & $-09 / 24 / 98$ & 72 & 61 & 2289 & 2243 \\
\hline CM7 & 82.5 & 75 & $\mathrm{U}$ & $-09 / 15 / 99$ & 86 & 18 & 775 & 411 \\
\hline CM8 & 72.3 & 59 & M & 07/17/99-09/17/99 & 63 & 16 & 3908 & 1688 \\
\hline CM9 & 50.9 & 17 & $\mathrm{U}$ & 07/20/99-09/22/99 & 65 & 30 & 1284 & 1567 \\
\hline CM10 & 71.3 & 61 & $\mathrm{U}$ & 08/01/99-09/03/99 & 34 & 34 & 584 & 643 \\
\hline CM11 & 67.5 & 44 & M & 08/05/99-09/17/99 & 44 & 20 & 978 & 1469 \\
\hline CM12 & 77.6 & 70 & $\mathrm{U}$ & $07 / 16 / 00-08 / 26 / 00$ & 41 & 46 & 781 & 849 \\
\hline
\end{tabular}

due to the termination of research seasons (CM1, CM3, CM6, CM9 and CM12). On 3 occasions, tracking was inhibited by the premature detachment of the VHF and sonic transmitters (CM5, CM10 and CM11). Transmissions of 4 turtles ceased for unknown reasons, but it is likely that these individuals either departed the study area or were poached (CM2, CM4, CM7 and CM8; see Seminoff 2000).

\section{Home range area}

There was substantial variation in home range size and shape among the 12 green turtles tracked during this

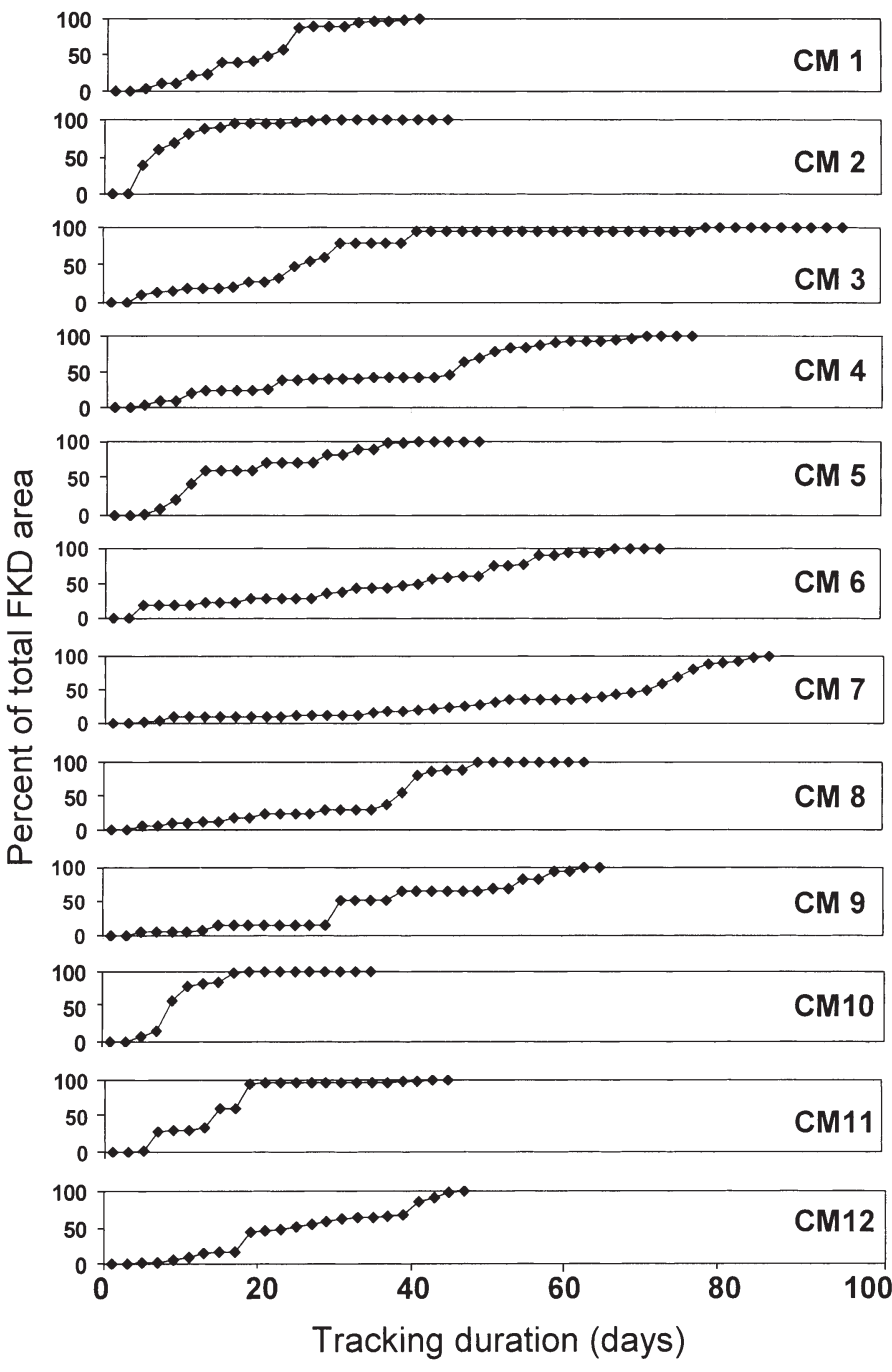

Fig. 3. Chelonia mydas. Incremental area plots for 12 green turtles tracked in Bahía de los Angeles (1997 to 2000) study (Fig. 2a,b). Minimum convex polygon and FKD home range estimates ranged from 584 to 3908 and 409 to 3231 ha, respectively (Table 1). Mean MCP area (1662 \pm 324 ha) was slightly larger than mean FKD area (1537 \pm 280 ha) but the medians were not different $(Z=-0.36, p=0.76)$. Home ranges were smallest among turtles whose movements were restricted to nearshore habitats in the El Bajo and La Gringa nearshore localities (CM1, CM3 and CM7). The largest home ranges were exhibited by turtles that moved between the marine algae pastures at El Rincon and El Bajo (CM4, CM5 and CM8), and turtles that commuted between insular and peninsular activity centers (CM2, CM6 and CM9).

Increment plots for the 12 green turtles tracked during this study are presented in Fig. 3. Among these, the home range of CM10 was the quickest to stabilize (Day 18 of 34 total tracking days) and the home range of CM3 was the slowest (Day 76 of 96 total tracking days). Three increment plots did not reach an asymptote (CM1, CM7 and CM12); however, these plots appear to approach stabilization, and therefore we believe that the respective home range estimates provide a reasonable measure of the home ranges used by these individuals. The mean incremental area plot for all turtles is shown in Fig. 4.

The GLM model regression analysis indicates that the home range estimates as determined with the MCP and FKD methods were independent of year of tracking effort, SCL, mass, sex, tracking interval and number of re-sightings $\left(\mathrm{R}^{2}{ }_{\mathrm{MCP}}=0.56, \mathrm{p}=0.81 ; \mathrm{R}^{2}{ }_{\mathrm{AK}}=0.29\right.$, $\mathrm{p}=0.98$ ). Moreover, when inspected individually no single covariate had a significant effect on home range area (Table 2). The relationships between straight carapace length, mass, tracking interval, and number of resightings and home range areas are plotted in Fig. 5. 


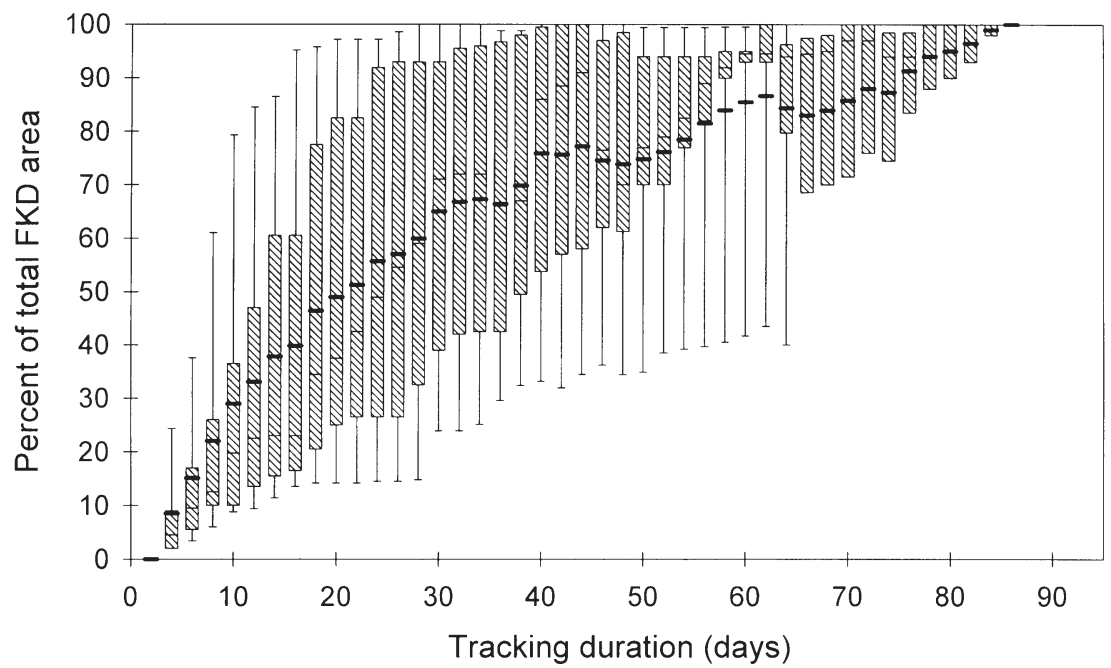

Fig. 4. Chelonia mydas. Mean incremental area plot for 12 green turtles tracked in Bahía de los Angeles. Each box is divided at the mean (thick line); box length is based on interquartile range; and the upper and lower whiskers mark the 25th and 75th quantiles
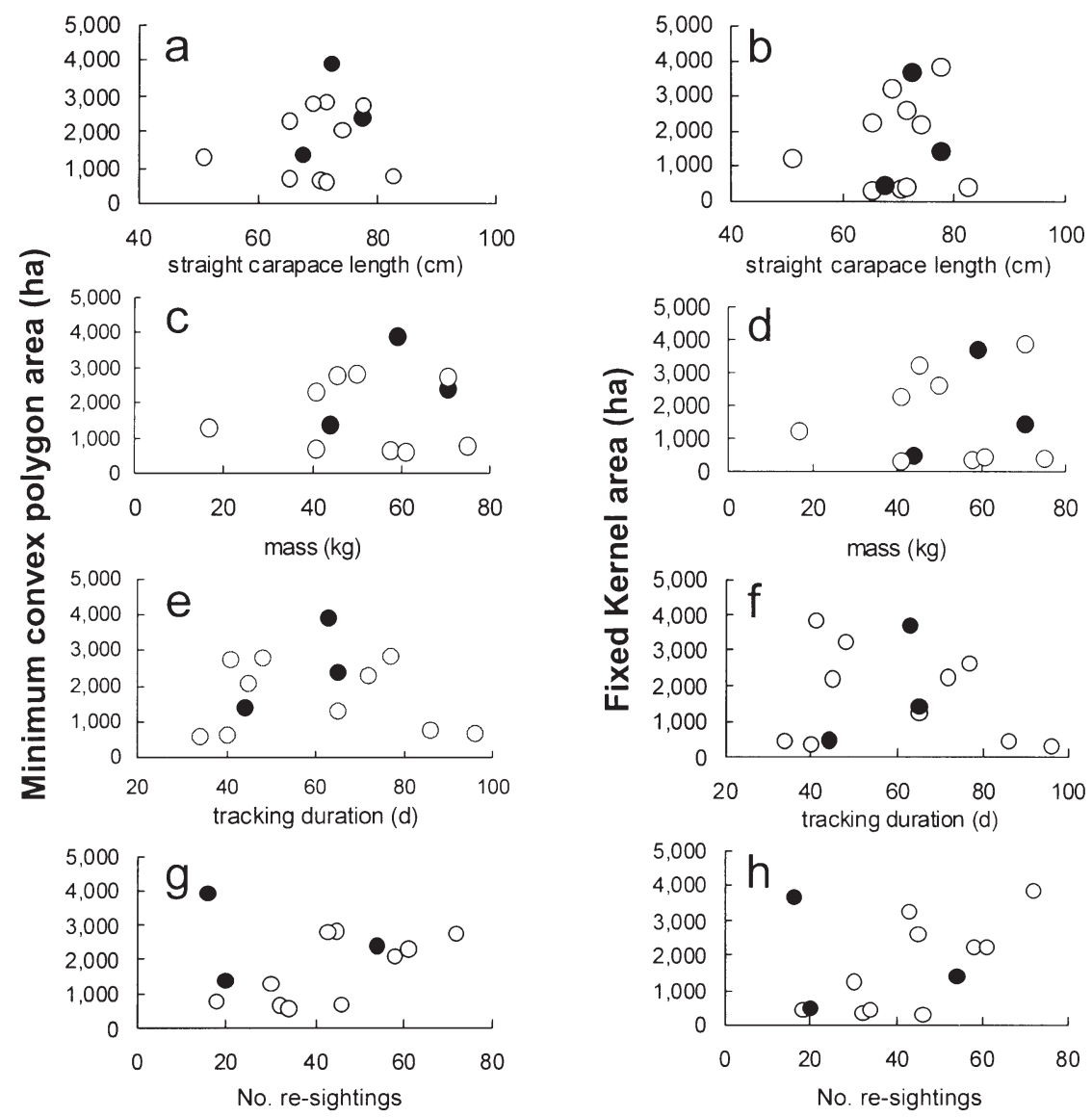

Fig. 5. Chelonia mydas. Relationship between GLM parameters (straight carapace length, mass, tracking duration and number of re-sightings), and home range area estimates based on the minimum convex polygon and fixed kernel density estimator for 12 green turtles tracked in Bahía de los Angeles. Males (•) and individuals of unknown gender $(\mathrm{O})$

\section{Activity centers}

Green turtle re-sighting positions were not uniformly distributed within the boundaries of their respective home ranges. All turtles exhibited disproportionately heavy use of peninsular shallows and/or insular near-shore habitats. Most turtles exhibited an affinity for a single activity center but 3 individuals (CM2, CM6 and CM9) moved between 2 activity centers, and 1 (CM7) used 3 activity centers (Fig. 2a,b). Activity centers varied in size, ranging from 3.8 to 642.2 ha $($ mean $=178.8 \pm$ $62.0 \mathrm{ha}$ ) and encompassed from 0.6 to $19.9 \%$ (mean $=10.3 \pm 2.0 \%$ ) of the respective FKD total area for each turtle. Among the home ranges that included 2 or more activity centers, the mean distance between activity centers was $2948 \pm 453 \mathrm{~m}$ (range $=1859$ to $4285 \mathrm{~m}$ ). Activity centers were found in all subregions with those of 8 turtles (CM2, CM3, CM4, CM5, CM7, CM9, CM10 and CM12) present at the El Bajo marine algae pasture; of 3 turtles at the Islands (CM2, CM6 and CM9); of 2 turtles at La Gringa (CM1 and CM11); and of 1 turtle (CM8) at El Rincon (Table 3).

\section{Water depth at re-sighting locations}

Seven of the 12 green turtles tracked during this study were encountered at least once in each of the 5 depth-class regions in the study area; the remaining 5 individuals (CM1, CM3, CM7, CM8 and CM10) were re-sighted in all but the deepest $(40+\mathrm{m})$ depth-class region (Fig. 6). Despite the widespread nature of re-sightings among the depth-class regions within Bahía de los Angeles, green turtles were not found with equal frequency among these regions during any temporal period $\left(\chi_{\text {diel }}^{2}=23.12, \mathrm{df}=4, \mathrm{p}=0.0001\right.$; $\chi_{\text {diurnal }}^{2}=25.59, \mathrm{df}=4, \mathrm{p}<0.0001$; $\chi_{\text {nocturnal }}^{2}=15.86, \mathrm{df}=4, \mathrm{p}=0.0032$ Table 4). Moreover, the distribution of re-sightings among depth classes varied significantly between the diurnal (D) and nocturnal $(\mathrm{N})$ periods (Kolmogorov-Smirnov D $=0.2135, \mathrm{p}<0.01$ ) 
Whereas the greatest proportion of resightings during the diurnal period $(28.25 \pm 0.06 \%)$ was in the 10 to $20 \mathrm{~m}$ depth class, the greatest proportion during the nocturnal period (38.66 \pm $0.09 \%$ ) was in the 0 to $10 \mathrm{~m}$ depth class (Fig. 7). The greatest frequency of resightings within the shallowest depth class (0 to $10 \mathrm{~m}$ ) was during the nocturnal period for all but 3 individuals (CM5, CM6 and CM12; Fig. 6).

\section{DISCUSSION}

The home ranges described in Bahía de los Angeles represent the first information on the scale of the movements and the habitat use of green turtles in neritic foraging habitats of the eastern Pacific Ocean. Sustained reductions of green turtle numbers in the Gulf of California may hinder future research in this region; nonetheless, we encourage additional studies using similar techniques to provide comparisons with the home ranges and habitat use patterns described here.

\section{Habitat use}

Green turtles were tracked in a variety of habitats throughout Bahía de los Angeles but were most commonly found along the shallow nearshore margins of the study area, particularly near El Bajo. The importance of this area is underscored by the overlap of the MCP home ranges of 11 of the 12 green turtles tracked during this study, and by the presence of core areas of 6 of these individuals at this site. Both telemetered and nontelemetered green turtles have been seen congregating in this area daily (J. A. Seminoff pers. obs.). Moreover, Seminoff (2000) reported that the El Bajo capture site had the highest catch per unit effort and greatest green turtle recapture rate during 7 yr of in-water capture efforts at Bahía de los Angeles. The abundance of food resources likely accounts for green turtle affinity for this locality. El Bajo contains the most extensive
Table 2. Chelonia mydas. Summary of GLM parameter estimates fitted to green turtle home range estimates based on minimum convex polygon and fixed kernel density methods. The $t$-test significance is based on $\mathrm{p}=0.05$; ns: not significant

\begin{tabular}{|lrrrr|}
\hline Parameter & Estimate & Standard error & t-ratio & Prob. $(t)$ \\
\hline Minimum Convex Polygon model & & & & \\
(Constant) & 5.9627 & 13.2213 & 0.45 & $\mathrm{~ns}$ \\
Year & -0.5673 & 1.3598 & -0.42 & $\mathrm{~ns}$ \\
Straight carapace length (log) & 0.0557 & 0.2487 & 0.22 & $\mathrm{~ns}$ \\
Mass (log) & -0.0320 & 0.1204 & -0.27 & $\mathrm{~ns}$ \\
Sex (M-U) & 0.3225 & 0.3531 & 0.91 & $\mathrm{~ns}$ \\
Number of days tracked & -0.0049 & 0.0173 & -0.29 & $\mathrm{~ns}$ \\
Number of re-sightings & -0.0149 & 0.0613 & -0.24 & $\mathrm{~ns}$ \\
& & & & \\
Fixed Kernel model & & & & \\
(Constant) & 2.8901 & 16.9567 & 0.17 & $\mathrm{~ns}$ \\
Year & -0.2548 & 1.7439 & -0.15 & $\mathrm{~ns}$ \\
Straight carapace length (log) & 0.0933 & 0.3190 & 0.29 & $\mathrm{~ns}$ \\
Mass (log) & -0.0414 & 0.1545 & -0.27 & $\mathrm{~ns}$ \\
Sex (M-U) & -0.0012 & 0.4528 & 0.00 & $\mathrm{~ns}$ \\
Number of days tracked & -0.0073 & 0.0222 & -0.33 & $\mathrm{~ns}$ \\
Number of re-sightings & 0.0033 & 0.0786 & 0.04 & $\mathrm{~ns}$ \\
\hline
\end{tabular}

Table 3. Chelonia mydas. Summary of number, location and total area of activity centers of green turtles as determined with the $50 \%$ kernel isopleth. • indicates 1 activity center. See Fig. 1 for location of regions

\begin{tabular}{|c|c|c|c|c|c|c|}
\hline \multirow{2}{*}{$\begin{array}{l}\text { Turtle } \\
\text { ID }\end{array}$} & \multicolumn{4}{|c|}{ Sub-region } & \multirow{2}{*}{$\begin{array}{c}\text { AC area } \\
\text { (ha) }\end{array}$} & \multirow{2}{*}{$\begin{array}{l}\% \text { of total } \\
\text { FKD area }\end{array}$} \\
\hline & La Gringa & El Bajo & El Rincon & Islands & & \\
\hline CM1 & $\bullet$ & & & & 130.2 & 17.1 \\
\hline CM2 & & $\bullet$ & & $\bullet$ & 246.2 & 11.3 \\
\hline CM3 & & - & & & 3.8 & 0.9 \\
\hline CM4 & & $\bullet$ & & & 588.9 & 19.7 \\
\hline CM5 & & - & & & 642.2 & 19.9 \\
\hline CM6 & & & & $\bullet$ & 140.9 & 6.3 \\
\hline CM7 & $\bullet$ & $\bullet$ & & & 65.5 & 15.9 \\
\hline CM8 & & & - & & 10.6 & 0.6 \\
\hline CM9 & & $\bullet$ & & $\bullet$ & 126.6 & 8.1 \\
\hline CM10 & & $\bullet$ & & & 79.1 & 12.3 \\
\hline CM11 & - & & & & 26.9 & 1.8 \\
\hline CM12 & & - & & & 85.0 & 10.0 \\
\hline
\end{tabular}

Table 4. Chelonia mydas. Proportions of re-sightings in the 5 water depth classes for 12 green turtles tracked in Bahía de los Angeles. Means are presented for diel $(24 \mathrm{~h})$, diurnal (05:00 to 18:59) and nocturnal (19:00 to 04:59 h) periods

\begin{tabular}{|c|c|c|c|c|c|c|}
\hline \multirow{2}{*}{$\begin{array}{l}\text { Depth } \\
\text { class } \\
\text { (m) }\end{array}$} & \multicolumn{2}{|c|}{$\begin{array}{c}\text { Diel } \\
(\mathrm{n}=444)\end{array}$} & \multicolumn{2}{|c|}{$\begin{array}{l}\text { Diurnal } \\
(\mathrm{n}=370)\end{array}$} & \multicolumn{2}{|c|}{$\begin{array}{l}\text { Nocturnal } \\
(\mathrm{n}=74)\end{array}$} \\
\hline & $\begin{array}{l}\text { Mean \% of } \\
\text { re-sightings }\end{array}$ & $\mathrm{SE}$ & $\begin{array}{l}\text { Mean \% of } \\
\text { re-sightings }\end{array}$ & $\mathrm{SE}$ & $\begin{array}{l}\text { Mean \% of } \\
\text { re-sightings }\end{array}$ & $\mathrm{SE}$ \\
\hline $0-10$ & 26.55 & 0.04 & 13.74 & 0.04 & 38.66 & 0.09 \\
\hline $10-20$ & 33.71 & 0.05 & 28.25 & 0.06 & 23.81 & 0.05 \\
\hline $20-30$ & 22.78 & 0.03 & 26.20 & 0.05 & 18.02 & 0.05 \\
\hline $30-40$ & 8.72 & 0.03 & 13.78 & 0.04 & 9.34 & 0.05 \\
\hline $40+$ & 8.21 & 0.03 & 18.01 & 0.08 & 9.53 & 0.07 \\
\hline
\end{tabular}


Fig. 6. Chelonia mydas. Frequency of re-sightings among water depth categories for 12 green turtles tracked in Bahía de los Angeles. Data are summarized by diurnal (D; $05: 00$ to $18: 59 \mathrm{~h}$ ) and

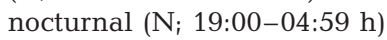
periods

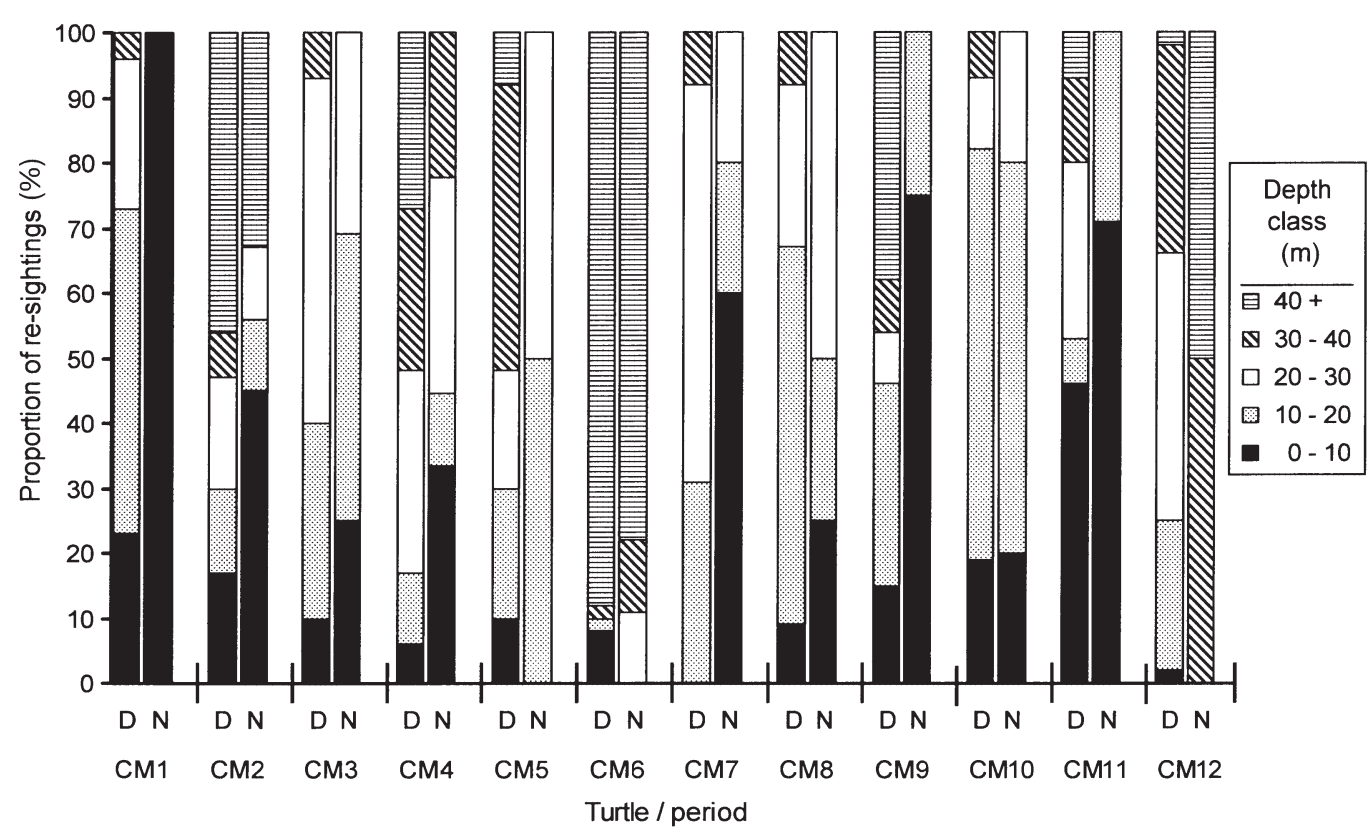

shallow water habitat in Bahía de los Angeles and hosts the largest marine algae pasture in the area (Pacheco-Rúiz et al. 1999). Dense algal stands dominated by Gracilariopsis lemaneiformis and Gracilaria robusta extend over $\sim 6$ ha (Pacheco-Rúiz et al. 1999). Seminoff et al. (2002) report that these red algae are the most common species consumed by green turtles in Bahía de los Angeles. Although primary diet constituents may vary regionally among different foraging areas (for review see Bjorndal 1997), the affinity with areas characterized by large patches of algae observed

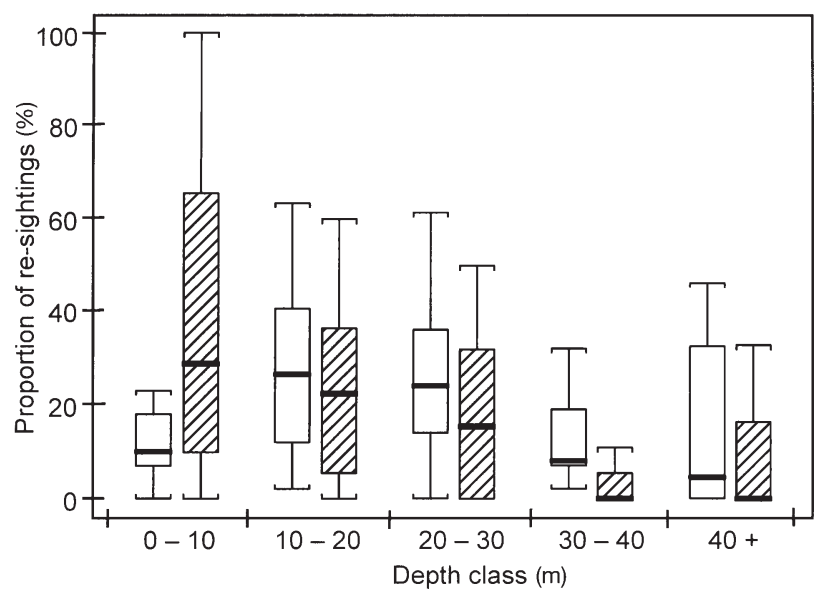

Fig. 7. Chelonia mydas. Distribution of re-sightings among water depth-classes by diurnal (05:00 to $18: 59 \mathrm{~h}_{\text {; }} \square$ ) and nocturnal $(19: 00$ to $04: 59 h ; \nabla)$ periods for 12 green turtles tracked in Bahía de los Angeles. Each box is divided at the median; box length is based on the interquartile range; and the upper and lower whiskers mark the 25 th and 75 th quantiles in this study is consistent with reports from other green turtle foraging grounds (Ogden et al. 1983, Whiting \& Miller 1998).

The timing of green turtle movements into nearshore habitats may be related to human activity. Whereas heavy boat traffic and fishing pressure in these areas occurred daily from sunrise to $\sim 1 \mathrm{~h}$ before sunset (J. A. Seminoff pers. obs.), green turtles were more consistently re-sighted in the shallowest waters $(0$ to $10 \mathrm{~m}$ depth) in the evening and at night. This temporal dichotomy suggests that green turtles may be purposefully avoiding these human activities. Similarly, Balazs et al. (1987) reported that Hawaiian green turtles visited nearshore foraging habitats primarily during nocturnal periods and suggested that this was a human avoidance tactic. Renaud et al. (1995) radio-tracked juvenile green turtles in the Gulf of Mexico and found that they associated more commonly with jetties that were not used heavily by people.

Green turtle movements over nearshore algae pastures are likely linked to foraging behavior, but their use of adjacent shallow-water habitats and deeper offshore areas devoid of algae is less clear. One of the major limitations of conventional radio and sonic telemetry is the lack of data on the vertical movement patterns. Therefore, it is not possible to unequivocally determine the behavior of the telemetered turtles when they are below the ocean surface. Nevertheless, we believe excursions away from algal pastures are associated with resting and/or foraging.

Departure from foraging pastures en route to resting sites has been shown for green turtles in Hawaii (Brill et al. 1995) and the US Virgin Islands (Ogden et al. 
1983). Mendonca (1983) showed that Florida green turtles fed on seagrass flats in mid-morning and midafternoon, and moved into deeper water during midday hours for resting. However, based on resting depth data from other studies, re-sightings in the deepest portions of Bahía de los Angeles are very likely not linked to resting behavior. Hays et al. (2000) have shown that adult green turtles in interesting habitat at Ascension Island typically rest at depths between 18 and $20 \mathrm{~m}$. Similarly, a sub-adult Hawaiian green turtle rarely exhibited resting behavior in depths $>14 \mathrm{~m}$ (Rice et al. 2000). Green turtles observed over deep waters of Bahía de los Angeles may thus have been moving between the primary foraging pastures or commuting to shallower foraging or resting sites at the islands. Traversal of waters $>30 \mathrm{~m}$ deep would be required for the 3 turtles (CM2, CM6 and CM9) that moved between El Bajo and activity centers at the island sites and the 4 turtles (CM4, CM5, CM8 and CM11) that moved between the El Bajo and El Rincon algae pastures.

The recovery of deep-water benthic invertebrates in diet samples suggests that green turtles may also forage in the deep mid-bay waters of Bahía de los Angeles (Seminoff et al. 2000, 2002). However, it is unknown whether these areas are visited specifically for foraging or whether green turtles opportunistically forage in deep-benthic habitats during commuting movements. Regardless, foraging on non-algal foods may be nutritionally beneficial to green turtles; thus, offsetting the costs of movement to, and deep diving in, these areas. Mixed diets have been shown for green turtles at a variety of foraging grounds with conventional diet analysis (for review see Bjorndal 1997) and more recently using stable isotope analysis (Godley et al. 1998). Nonadditive benefits of ingesting a mixed diet have been shown for freshwater turtles (Bjorndal 1991). In particular, invertebrate foods perhaps make a major contribution of vitamins, trace minerals or essential amino acids for herbivorous green turtles (Bjorndal 1990, Hirth et al. 1992).

\section{Home range size}

There are few home range estimates for green turtles but those available describe substantially smaller MCP areas than found in this study (mean = 1662 ha). Mendonca (1983), for instance, found summer home ranges of immature Chelonia mydas from 48 to 506 ha in a Florida lagoon. Renaud et al. (1995) described home ranges of 22 to 311 ha for juvenile green turtles in the Gulf of Mexico, and Whiting \& Miller (1998) reported short-term foraging ranges from 84 to 850 ha for adult green turtles in Australia. Comparisons among these studies should, however, be made with caution as each study tracked different-sized green turtles within distinct foraging habitats and for varying durations.

The large size of Bahía de los Angeles and the scattered distribution of marine algae pastures may explain the large home ranges of green turtles described in this study. Bahía de los Angeles is roughly $60 \mathrm{~km}^{2}$; the 3 primary algae pastures along the peninsula are separated by a minimum of $8 \mathrm{~km}$ (Pacheco-Ruiz et al. 1999) and occur at least $5 \mathrm{~km}$ from insular habitats. Green turtles moving among these areas must therefore traverse large open water stretches. In contrast, Mendonca (1983) described green turtle home ranges in a Florida lagoon that was $54 \mathrm{~km}$ long, but only $4 \mathrm{~km}$ wide at its widest point. Renaud et al. (1995) carried out their study at jetty habitats in the Gulf of Mexico where home ranges of tracked green turtles were likely restricted by the narrow size of the jetty channels. Moreover, the largest turtle in the Gulf of Mexico study (47.9 cm SCL; Renaud et al. 1995) was notably smaller than the smallest individual tracked in Bahía de los Angeles (50.9 cm SCL). Although the present study does not show a significant size effect on home range area, turtle size has been shown to affect home range when small juveniles and larger sub-adults are tracked and analyzed together (Mendonca 1983).

In general, green turtle home ranges are substantially smaller than those reported for loggerhead turtles (Renaud \& Carpenter 1994) but larger than those described for immature hawksbill turtles (van Dam \& Diez 1998). Whereas green turtle home range sizes reported here and elsewhere range from 22 to 3908 ha, loggerhead turtle home ranges in the northern Gulf of Mexico were 95400 to 2883300 ha (Renaud \& Carpenter 1994) and immature hawksbill turtle home ranges at Mona Island, Puerto Rico were 7 to 21 ha (van Dam $\&$ Diez 1998). The differences in home range size observed in these studies may be related to varying foraging ecologies, individual sizes, and/or marine zones inhabited by the tracked turtles. However, although the potential effects of these intrinsic and extrinsic factors are intriguing, additional data for each species are needed to further elucidate interspecies differences in home range area.

\section{Seasonality of home range size}

As ectotherms, sea turtles are constrained by climatic as well as physical factors affecting the surrounding environment (Spotila et al. 1997). At Bahía de los Angeles, seasonal climatic changes may elicit seasonal variation in green turtle activity. This is one of the northernmost major foraging areas for green turtles in the eastern Pacific Ocean and, as a temperate 
marine ecosystem, experiences substantial seasonal fluctuations in ocean temperature. While summer sea surface temperature at Bahía de los Angeles approaches $30.0^{\circ} \mathrm{C}$, winter sea surface temperature drops below $14.5^{\circ} \mathrm{C}$ (Seminoff 2000). Although the implications of changing ocean temperature are not fully understood, it is likely that green turtles inhabiting temperate foraging grounds exhibit seasonal changes in home range size and scale of movements. For instance, green turtles at an adjacent foraging area in the Gulf of California exhibited overwintering torpor during cold-water periods (Felger et al. 1976). In the present study, seasonal differences in home range could not be investigated as all turtles were only tracked during summer (June to October). We therefore stress that the spatial scale of home range and movements reported here may be specific to warmwater periods only.

\section{Effect of tagging}

Because telemetered specimens are studied for the purpose of extrapolation to untagged individuals, it is important to consider the extent to which results are biased by the effects of the telemetry package. We believe the transmitters used in this study had negligible effects on the home range of green turtles examined during this study because of the following: (1) telemetered turtles seemed to exhibit normal behavior, swimming ability and physical appearance; (2) during tracking efforts, turtles returned to areas of initial capture, suggesting that the transmitters and the tagging experience left no lasting effect on habitat use patterns; (3) the maximum weight of transmitter packages during this study was $1.2 \%$ of body mass, and studies on fish (Mellas \& Haynes 1985) have shown that a transmitter will not cause negative effects if its weight is less than $2 \%$ of the tracked individual's body mass; (4) the use of transmitter fairings as applied to the VHF transmitters used in this study has been shown to substantially reduce hydrodynamic drag of backpack mounted satellite transmitters in experimental conditions (Watson \& Granger 1998); and (5) during tracking sessions, both telemetered and nontelemetered turtles were seen in the same areas exhibiting roughly similar surface behavior, even swimming within meters of our tracking vessel; thus, suggesting negligible effects of the transmitter packages.

\section{Use of multiple home range estimators}

A variety of analytical techniques have been developed to evaluate home range size and activity patterns but few have been applied to sea turtles. Our use of MCP and FKD home range estimator methods provided 2 alternate descriptions of green turtle home range. Despite the lack of a significant difference in median home range size between the 2 estimates, there were substantial differences in their descriptive properties. The FKD technique revealed up to 3 areas of disproportionately high use (i.e. core areas) per home range and did not incorporate vast areas separating outlying re-sighting positions from primary use areas. In contrast, the MCP was strongly related to the distribution of the outermost points and was prone to incorporating areas of non-use that separated patches of highly-used habitat (Worton 1987, White \& Garrot 1990). Moreover, the MCP method did not indicate how intensively different parts of each turtle's home range were used. Despite being a biologically less suitable descriptive statistic (White \& Garrot 1990), the MCP method is, however, a more widely used and comparable home range estimation approach (Gallerani-Lawson \& Rodgers 1997). We therefore recommend that future sea turtle home range studies employ at least 2 home range estimators and that 1 of these be the MCP technique, to facilitate comparisons with previous studies.

\section{Conservation implications}

Historic records indicate that Bahía de los Angeles supported a green turtle population considerably larger than that present today (Caldwell 1963). Despite decades of legal and illegal harvest (Caldwell 1963, Cliffton et al. 1982, Seminoff 2000), our study indicates that green turtles continue to reside at this coastal foraging area. Although the widespread re-sightings show that multiple sub-regions within Bahía de los Angeles are visited by green turtles, the preponderance of home range activity centers at El Bajo indicates that marine algae pastures of this sub-region provide the most critical habitat. The results of this study suggest that increased human activities may adversely impact the health of this foraging system. Although Bahía de los Angeles has a long history of net fisheries that have been shown to cause substantial green turtle mortality (Seminoff 2000, authors' unpubl. data), of perhaps greater threat is the habitat degradation resulting from the recently initiated commercial harvest of marine algae from the El Bajo sub-region (J. A. Seminoff pers. obs.) and the planned development of a large-scale marina in Bahía de los Angeles (Escalera Náutica; Anonymous 2001). The ongoing and potential impacts from these human activities underscore the need to develop and implement management strategies that protect local green turtles and their food resources. 
Acknowledgements. Financial and logistical support was provided by the Center for Field Research at Earthwatch Institute, Wallace Research Foundation and the PADI Foundation. We thank the following individuals for their generous assistance: L. Bartley, F. Clemente, S. Collins, L. Cragin, S. Eckert, J. Gilmore, G. Joder, T. Jones, A. Juarez, S. Juarez, R. Lawson, E. Massie, F. Paladino, S. Presti, B. Resendiz, M. Rosini, T. Smith, L. Yarnell and all the Earthwatch Team members. A. Bolten, B. Godley, K. Reich and C. Schwalbe provided helpful comments on earlier versions of this manuscript. Research was authorized by Secretaria del Medio Ambiente, Recursos Naturales, y Pesca, México (Permit Nos. 150496-213-03, 190698-213-03, 280499-213-03 and 280597-213-03). All animal handling was in full compliance with IACUC protocol at the University of Florida.

\section{LITERATURE CITED}

Alvarado J, Figueroa A (1992) Recapturas post-anidatorias de hembras de tortuga marina negra (Chelonia agassizi) marcadas en Michoacán, México. Biotropica 24:560-566

Alvarado-Díaz J, Delgado-Trejo C, Suazo-Ortuño I (2001) Evaluation of black turtle project in Michoacán, México. Mar Turt Newsl 92:4-7

Anonymous (2001) Proyecto Escalera Náutica del Mar de Cortés: documento basico. Fondo Nacional de Fomento al Turismo, Mexico City

Bailey JA (1984) Principles of wildlife management. WileyLiss, New York

Balazs GH, Forsyth RG, Kam AKH (1987) Preliminary assessment of habitat utilization by Hawaiian green turtles in their resident foraging pastures. NOAA Tech Memo NMFS-SWFC-71. US Dep Comm, Washington, DC

Balazs GH, Russell KM, Beaver SC (1996) Procedures to attach a satellite transmitter to the carapace of an adult green turtle, Chelonia mydas. In: Keinath JA, Barnard DE, Musick JA, Bell BA (eds) Proc 15th Annu Symp Sea Turtle Biol Conserv. NOAA Tech Memo NMFS-SEFSC-387, p 21-26

Bjorndal KA (1990) Digestibility of the sponge Chondrilla nucula in the green turtle, Chelonia mydas. Bull Mar Sci 47:567-570

Bjorndal KA (1991) Diet mixing: nonadditive interactions of diet items in an omnivorous freshwater turtle. Ecology 72 : 1234-1241

Bjorndal KA (1997) Foraging ecology and nutrition of sea turtles. In: Lutz PL, Musick JA (eds) The biology of sea turtles. CRC Press, Boca Raton, FL, p 199-232

Bray NA, Robles JM (1991) Physical oceanography of the Gulf of California. In: Dauphin JP, Simoneit BRT (eds) The Gulf and Peninsular Province of the Californias. Am Assoc Petrol Geol, Tulsa, OK, p 511-533

Brill RW, Balazs GH, Holland KN, Chang RKC, Sullivan S, George JC (1995) Daily movements, habitat use, and submergence intervals of normal and tumor-bearing juvenile green turtles (Chelonia mydas L.) within a foraging area in the Hawaiian Islands. J Exp Mar Bio Ecol 185: 203-218

Brusca R (1980) Common intertidal invertebrates of the Gulf of California. University of Arizona Press, Tucson

Burt WH (1943) Territoriality and home range concepts as applied to mammals. J Mammal 24:346-352

Caldwell DK (1963) The sea turtle fishery of Baja California, Mexico. Calif Fish Game 49:140-151

Carr A (1986) The sea turtle: so excellent a fishe. University of Texas Press, Austin
Carr A (1987) New perspectives on the pelagic stage of sea turtle development. Conserv Biol 1:103

Carr A, Meylan AB (1980) Evidence of passive migration of green turtle hatchlings in Sargassum. Copeia 1980:366-368

Cliffton K, Cornejo DO, Felger RS (1982) Sea turtles of the Pacific coast of México. In: Bjorndal KA (ed) Biology and conservation of sea turtles. Smithsonian Institution Press, Washington, DC, p 199-209

Cohen J, Cohen P (1983) Applied multiple regression/correlation analysis in the behavioral sciences, 2nd edn. Lawrence Erlbaum, New York

Dixon KR, Chapman JA (1980) Harmonic mean measure of animal activity areas. Ecology 61:1040-1044

Felger RS, Cliffton K, Regal PJ (1976) Winter dormancy in sea turtles: independent discovery and exploitation in the Gulf of California, Mexico, by two local cultures. Science 191: $283-285$

Figueroa A, Alvarado J, Hernández F, Rodríguez G, Robles J (1993) The ecological recovery of sea turtles of Michoacán, México. Special attention to the black turtle (Chelonia agassizi). Final Report to WWF-USFWS. US Fish \& Wildlife Serv, Albuquerque, NM

Gallerani-Lawson EJ, Rodgers AR (1997) Differences in home-range size computed in commonly used software programs. Wildl Soc Bull 25:721-729

Gardner SC, Nichols WJ (2001) Assessment of sea turtle mortality rates in the Bahía Magdalena region, Baja California Sur, México. Chelonian Conserv Biol 4:197-199

Godley BJ, Thomson DR, Waldron S, Furness RW (1998) The trophic status of marine turtles as determined by stable isotope analysis. Mar Ecol Prog Ser 166:277-284

Gonzalez-Solis J, Croxall JP, Wood AG (2000) Foraging partitioning between giant petrels Macronectes spp. and its relationship with breeding population changes at Bird Island, South Georgia. Mar Ecol Prog Ser 204:279-288

Groombridge B, Luxmoore R (1989) The green turtle and hawksbill (Reptilia: Cheloniidae): world status, exploitation and trade. United Nations Environment Programme, Cambridge

Hansteen TL, Andreassen HP, Ims RA (1997) Effects of spatiotemporal scale on autocorrelation and home range estimators. J Wildl Manage 61:280-290

Hays GC, Adams CR, Broderick AC, Godley BJ, Lucas DJ, Metcalfe JD, Prior AA (2000) The diving behaviour of green turtles at Ascension Island. Anim Behav 59:577-586

Hilton-Taylor C (2000) 2000 IUCN Red list of threatened species. IUCN, Gland, Switzerland and Cambridge, UK, p $1-61$

Hirth HF (1997) Synopsis of the biological data on the green turtle, Chelonia mydas (Linnaeus 1758). Biol Rep US Fish Wildl Serv 97-1

Hirth HF, Huber M, Frohm T, Mala T (1992) A natural assemblage of immature green (Chelonia mydas) and hawksbill (Eretmochelys imbricata) turtles on the fringing reef of Wuvulu Island, Papua New Guinea. Micronesica 25: 145-153

Hyrenbach KD, Fernández P, Anderson DJ (2002) Oceanographic habitats of two sympatric North Pacific albatrosses during breeding season. Mar Ecol Prog Ser 233:283-301

Kenward RE (2001) A manual for wildlife radio tagging. Academic Press, San Diego

Limpus CJ (1995) Global overview of the status of marine turtles: a 1995 viewpoint. In: Bjorndal KA (ed) Biology and conservation of sea turtles, 2nd edn. Smithsonian Institution Press, Washington, DC, p 605-610

Limpus CJ, Cooper PJ, Read MA (1994) The green turtle, Chelonia mydas, in Queensland: population structure in a 
warm temperate feeding area. Mem Queensl Mus 35: $139-154$

Mellas EJ, Haynes JM (1985) Swimming performance and behavior of rainbow trout (Salmo garidneri) and white perch (Morone Americana): effects of attaching telemetry transmitters. Can J Fish Aquat Sci 42:488-493

Mendonca MT (1983) Movements and feeding ecology of immature green turtles (Chelonia mydas) in a Florida lagoon. Copeia 1983:1013-1023

Mortimer JA, Portier KM (1989) Reproductive homing and internesting behaviour of the green turtle (Chelonia mydas) at Ascension Island, South Atlantic Ocean. Copeia 1989: 962-977

Musick JA, Limpus CJ (1997) Habitat utilization and migration in juvenile sea turtles. In: Lutz PL, Musick JA (eds) The biology of sea turtles. CRC Press, Boca Raton, FL, p 137-163

National Marine Fisheries Service and US Fish and Wildlife Service (1998) Recovery plan for US Pacific populations of the East Pacific green turtle (Chelonia mydas). National Marine Fisheries Service, Silver Spring, MD

Ogden JC, Robinson L, Whitlock K, Daganhardt H, Cebula R (1983) Diel foraging patterns in juvenile green turtles (Chelonia mydas L.) in St. Croix, United States Virgin Islands. J Exp Mar Biol Ecol 66:199-205

Pacheco-Ruíz I, Zertuche-González JA, Arellano-Carbajal F, Chee-Barragán A, Correa-Díaz F (1999) Gracilariopsis lemaneiformis beds along the West Coast of the Gulf of California, Mexico. Hydrobiologia 398/399:509-514

Renaud ML, Carpenter JA (1994) Movements and submergence patterns of loggerhead turtles (Caretta caretta) in the Gulf of Mexico determined through satellite telemetry. Bull Mar Sci 55:1-15

Renaud ML, Carpenter JA, Williams JA, Manzella-Tirpak SA (1995) Activities of juvenile green turtles, Chelonia mydas, at a jettied pass in south Texas. Fish Bull 93:586-593

Rice MR, Balazs GH, Hallacher L, Dudley W, Watson G, Krusell K, Larson B (2000) Diving, basking, and foraging patterns of a sub-adult green turtle at Punalu'u, Hawaii. In: Abreu-Grobois FA, Briseño-Duenas R, Márquez-Millán R, Sarti-Martinez L (eds) Proc 18th Annu Int Sea Turtle Symp. NOAA Tech Memo NMFS-SEFSC-438, p 229-231

Ridgway SH, Wever EG, McCormick JG, Palin J, Anderson JH (1969) Hearing in the giant sea turtle, Chelonia mydas. Proc Natl Acad Sci 64:884-890

SAS Institute (1996) A guide to statistical and data analysis using JMP and JMP IN software. Duxbury Press, Belmont, NY

Schmid JR, Bolten AB, Bjorndal KA, Lindberg WJ (2002)

Editorial responsibility: Otto Kinne (Editor),

Oldendorf/Luhe, Germany
Activity patterns of Kemp's ridley turtles (Lepidochelys kempii) in the coastal waters of the Cedar Keys, Florida. Mar Biol 140:215-228

Seaman DE, Powell RA (1996) An evaluation of the accuracy of kernel density estimators for home range analysis. Ecology 77:2075-2085

Seminoff JA (2000) Biology of the East Pacific green turtle, Chelonia mydas agassizii, at a warm temperate feeding area in the Gulf of California, México. PhD thesis, University of Arizona, Tucson

Seminoff JA, Nichols WJ, Resendiz A (2000) Chelonia mydas agassizii (East Pacific green turtle) diet. Herpetol Rev 31: 103

Seminoff JA, Resendiz A, Nichols WJ (2002) Diet of East Pacific green turtles (Chelonia mydas) in the central Gulf of California, México. J Herpetol 36:447-453

Silverman BW (1986) Density estimation for statistics and data analysis. Chapman \& Hall, London

Spotila JR, O'Connor MP, Paladino FV (1997) Thermal biology. In: Lutz PL, Musick JA (eds) The biology of sea turtles. CRC Press, Boca Raton, FL, p 297-314

Swihart RK, Slade NA (1985) Influence of sampling interval on estimates of home-range size. J Wildl Manage 49: 1019-1025

van Dam RP, Diez CE (1998) Home range of immature hawksbill turtles (Eretmochelys imbricata L.) at two Caribbean islands. J Exp Mar Biol Ecol 220:15-24

Watson KP, Granger RA (1998) Hydrodynamic effect of a satellite transmitter on a juvenile green turtle (Chelonia mydas). J Exp Biol 201:2497-2505

White GC, Garrott RA (1990) Analysis of wildlife radiotracking data. Academic Press, New York

Whiting SD, Miller JD (1998) Short term foraging ranges of adult green turtles (Chelonia mydas). J Herpetol 32: 330-337

Wibbels TH (1999) Diagnosing the sex of sea turtles in foraging habitats. In: Eckert KL, Bjorndal KA, Abreu-Grobois FA, Donnelly M (eds) Research and management techniques for the conservation of sea turtles. IUCN/SSC Mar Turt Spec Group Pub No. 4. Marine Turtle Specialist Group, Washington, DC, p 139-143

Wood AG, Naef-Daenzer B, Prince P, Croxall JP (2000) Quantifying habitat use in satellite-tracked pelagic birds: application of kernel estimation to albatross locations. J Avian Biol 31:278-286

Worton BJ (1987) A review of models of home range for animal movement. Ecol Model 38:277-298

Worton BJ (1989) Kernel methods for estimating the utilization distribution in home-range studies. Ecology 70:164-168

Submitted: May 7, 2002; Accepted: July 18, 2002

Proofs received from author(s): October 18, 2002 